REPORTS OF MORPHOLOGY
Official Journal of the Scientific Society of Anatomists,
Histologists, Embryologists and Topographic Anatomists
of Ukraine
journal homepage: https://morphology-journal.com

\title{
Effect of exogenous melatonin and flaxseed oil on the expression state of MT1 receptors in rat skin under light deprivation
}

\section{Sobolevskaya I.S., Krasnobaeva M.I., Myadelets O.D.}

Vitebsk State Order of Friendship of Peoples Medical University, Vitebsk, Belarus

\section{ARTICLE INFO}

Received: 18 February 2021

Accepted: 9 April 2021

UDC: $619: 612.821 .014: 612.018 .2]$ :

303.447.3

\section{CORRESPONDING AUTHOR}

e-mail: irinasobolevskaya1986@gmail.com Sobolevskaya I.S.

\begin{abstract}
Most of the skin cells have their own autonomous functional circadian system, which is able to control physiological and biochemical processes in the general integument. $A$ special role in these processes is assigned to the "clock" hormone of the pineal gland, melatonin, which acts on target cells through specific receptors (MT1, MT2, MT3 and $R O R \alpha$ ). Any disturbance of circadian rhythms can lead to rearrangements (disturbances) in the receptor apparatus of the cells of the general cover, which require a certain correction. Consequently, there is a need to search for effective and reliable drugs that will prevent the negative consequences caused by chronodestruction. In the present work, we studied the effectiveness of the effect of exogenous melatonin and flaxseed oil on the expression of MT1 receptors in the general coat of rats under light deprivation. An experimental study was carried out on 130 white outbred male rats (170-220 g), which were randomly divided into 5 groups: intact, light deprivation animals, light deprivation animals, which were injected intragastrically with flaxseed oil and melatonin. On days 7 , 14 and 21, histological material was taken (fragments of the skin of the interscapular region of the back). For immunohistochemical studies, serial sections were stained using MTNR1A polyclonal antibodies. For morphometric data analysis, the Image Scope Color and ImageJ computer programs were used. All statistical data processing was performed using the Statistica 10.0 software. Differences were considered significant at a significance level of less than $0.01(p<0.01)$. In the course of the experiment, it was found that light deprivation contributes to a change in the activity of expression of the MT1 melatonin receptors in the epidermis, sebaceous glands and hair follicles. Studies have shown that the administration of flaxseed oil, melatonin, and their combination to rats with desynchronosis is accompanied by the leveling of the adverse effect of desynchronosis on the studied parameters of MT1 receptors. The most pronounced corrective effect on the expression of MT1 receptors is observed with the introduction of exogenous melatonin on the 21st day of the experiment.
\end{abstract}

Keywords: melatonin MT1 receptors, epidermis, sebaceous glands, hair follicles, melatonin, flaxseed oil, light deprivation.

\section{Introduction}

Circadian rhythms have a significant impact on many structures of the skin. Any shifts in circadian rhythms lead to a disruption in the production of the hormone - melatonin, which contributes to serious changes in the work of the general and local circadian systems in the body. Since melatonin affects target cells through receptors (MT1, MT2, MT3 and ROR $\alpha$ ), any quantitative fluctuations in it can lead to modulation of reactions and changes in the state of the receiving part $[4,12,13,15]$.

The MT1 and MT2 melatonin receptors are expressed in skin cells, which are involved in the regulation of many of its physiological processes and defense mechanisms.
MT1 receptors have the highest sensitivity and degree of binding. Their distinctive feature is their high sensitivity to melatonin. The MT1 receptor also plays a key role in the regulation of the cutaneous circadian clock $[3,4,7,12,13$, 15].

Although constant darkness (light deprivation) is rarely considered as a cause of changes in the state of the circadian clock (compared to exposure to constant light), its effect on humans and animals is no less dangerous. Consequently, any disturbance of circadian rhythms can lead to rearrangements in the receptor apparatus of the cells of the general cover, cause disturbances in its 
morphofunctional state and, as a consequence, lead to skin diseases [4, 12].Consequently, there is a need to search for effective and reliable drugs that will prevent the negative consequences caused by chronodestruction. So, first of all, to restore a specific response, replacement therapy with an appropriate agonist is required [8, 10, 22]. Considering that melatonin synthesis changes under constant darkness, the use of its synthetic analogs should have a direct effect on the body. At the same time, the amino acid nature of the hormone ensures its bioavailability, and absorption occurs at the level of substrates.

In recent years, much attention has also been paid to the search for an alternative natural source of melatonin. Thus, this hormone has been identified and quantified both in products of animal and plant origin [14]. It has been established that the highest concentration of this phytohormone is possessed by some plant seeds, from which vegetable oils are subsequently obtained (flaxseed, olive, amaranth, walnut oil, etc.) In this regard, linseed oil is the most economically available and effective. In addition, this vegetable oil is of great interest because of the high content of essential fatty acids that are not synthesized in the human body: linoleic, $\alpha$-linolenic and $y$-linolenic [2, 14, $16,18]$.

At the same time, there is practically no information on the features of the effect of melatonin and flaxseed oil on changes in the number (occupied area) and density of MT1 receptors on target cells, and the question of such a relationship remains open.

The efficacy of flaxseed oil and melatonin can be enhanced and side effects mitigated when they are combined wisely. Moreover, the nature and direction of their joint action may differ significantly from the impact of individual components [19].

At present, the prevention and correction of disorders caused by desynchronosis in the body in general and in the general cover in particular require increased attention, and the possibility of stimulating MT1 receptors can be considered as a promising strategy for improving the general condition of the skin.

The aim of the study was to substantiate the possibility of correction by exogenous melatonin and flaxseed oil of changes in the expression of MT1 receptors in the skin of white male rats, caused by light deprivation.

\section{Materials and methods}

An experimental study was carried out on 130 white outbred male rats (170-220 g), which were randomly divided into 5 groups (Table 1). All animals were kept in standard vivarium conditions on an optimal diet. Morphological changes in the general cover of the animals were assessed on days 7,14 and 21 .

All manipulations with rats were carried out in accordance with the following regulatory documents: "European Convention for the Protection of Vertebrate Animals used for Experiments or Other Scientific
Table 1. Characteristics of animals experimental groups.

\begin{tabular}{|c|c|}
\hline Group & Description \\
\hline Intact ( $\mathrm{n}=10)$ & Animals exposed to standard fixed lighting (12 $\mathrm{h}$ \\
light/12 h dark)
\end{tabular}

Purposes (Strasbourg, 03/18/1986, ETS No. 123), EEC Council Directives (11/24/1986), FELASA (1994-1996), TCP 125-2008 and "Rules of Laboratory Practice of the Republic of Belarus", Protocol-design of the experiment (approved by the VSMU Commission on Bioethics and Humane Treatment of Laboratory Animals).

For immunohistochemical studies, skin fragments (interscapular region of the back) were fixed in a $10 \%$ solution of neutral buffered formalin (24 hours). Then the histological material was embedded in paraffin and serial sections were made. The preparations were stained immunohistochemically using polyclonal antibodies MTNR1A (Elabscience, USA). For immunohistochemical staining, a fully automated Leica Microsystems Bond-maX immunohistostainer was used. As a result of the reaction, MT1-positive areas were stained brown or yellowish.

Histological changes in the preparations were assessed at $\times 200, \times 400$ magnifications. The morphological assessment of the expression of MT1 receptors was carried out using a computerized image analysis system (licensed software Leica Aplication Suite, Version 3.6.0). For morphometric analysis of the data, we used the licensed computer program for image analysis Image Scope Color, as well as the image processing software ImageJ. An automatic assessment was made of the percentage of MT1-positive sites (filling factor, \%) and the nature of cytoplasmic expression in immunopositive sites (expression intensity factor, standard units).

Statistical data processing was performed using the Statistica 10.0 software. Methods of nonparametric statistics were used. Statistical hypotheses of equality of 
the general population means were tested using the $U$ (Mann-Whitney), W (Wilcoxon), and $\mathrm{H}$ (Kruskal-Wallis) tests with the accepted significance level $\alpha=0.05$.

\section{Results}

According to previous studies, the 24-hour stay of experimental animals in the dark led to significant changes in the expression of MT1 receptors [1]. Thus, on the 7th day, in the keratinocytes of the epidermis and sebocytes of the sebaceous glands, the filling factor of MT1 receptors decreased with a simultaneous increase in the intensity factors of their expression in these structures (Fig. 1, 2). Along with this, an increase in all the studied parameters was observed in the hair follicles. At the same time, the level of immunopositive cells and the intensity of their expression increased (Fig. 1,2).

Intragastric administration of flaxseed oil, melatonin and their combination to experimental animals for 7 days in constant darkness was accompanied by changes in the expression of membrane melatonin receptors in the general cover. Thus, in the cells of the epidermis and sebaceous glands, the use of flaxseed oil, as well as melatonin, prevented a sharp decrease in the level of MT1positive cells, compared with rats in the light deprivation group $(p<0.001)$ (see Fig. 1, 2). Higher efficacy was observed in animals that were injected with exogenous melatonin. At the same time, the combined use of the oil and the hormone led to a much significant decrease in the filling factors of MT1 receptors in these skin structures relative to animals in complete darkness (Fig. 1, 2, 3).

The change in the intensity of MT1 immunohistochemical staining on the 7th day of the experiment in the epidermis, sebaceous glands and hair follicles was observed only in animals that were simultaneously injected with flaxseed oil and melatonin (Fig. 4, 5, 6). Thus, in rats of this group, the values of the expression intensity coefficients corresponded to the control parameters. In other animals, there were no significant changes in the indicator.

The study of histological skin preparations obtained on the 14th day of exposure to light deprivation showed a further decrease in the filling factors of MT1 receptors in comparison with intact animals in the epidermis and sebaceous glands. A similar pattern was observed in hair
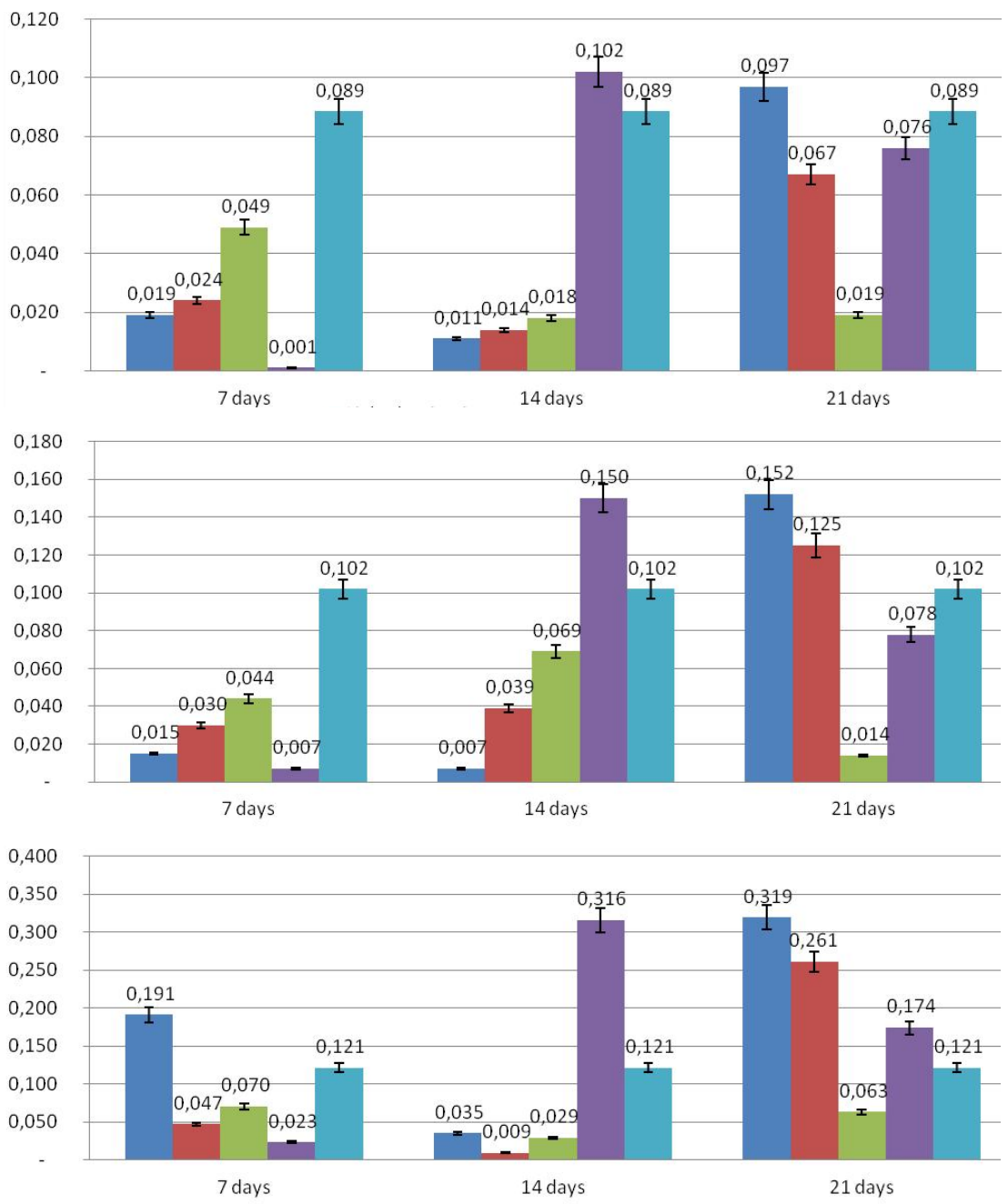

- Light deprivation

- Light deprivation using linseed oil - Light deprivation using melatonin

- Light deprivation using melatonin and linseed oil Control group

Fig. 1. Filling factor of MT1 receptors in the epidermis during light deprivation (\%).

\section{n Light deprivation}

- Light deprivation using linseed oil

- Light deprivation using melatonin

- Light deprivation using melatonin and linseed oil - Control group

Fig. 2. Filling factor of MT1 receptors in the sebaceous glands during light deprivation (\%).

\section{- Light deprivation \\ - Light deprivation using linseed oil - Light deprivation using melatonin \\ - Light deprivation using melatonin and linseed oil - Control group}

Fig. 3. Filling factor of MT1 receptors in hair follicles during light deprivation (\%). 

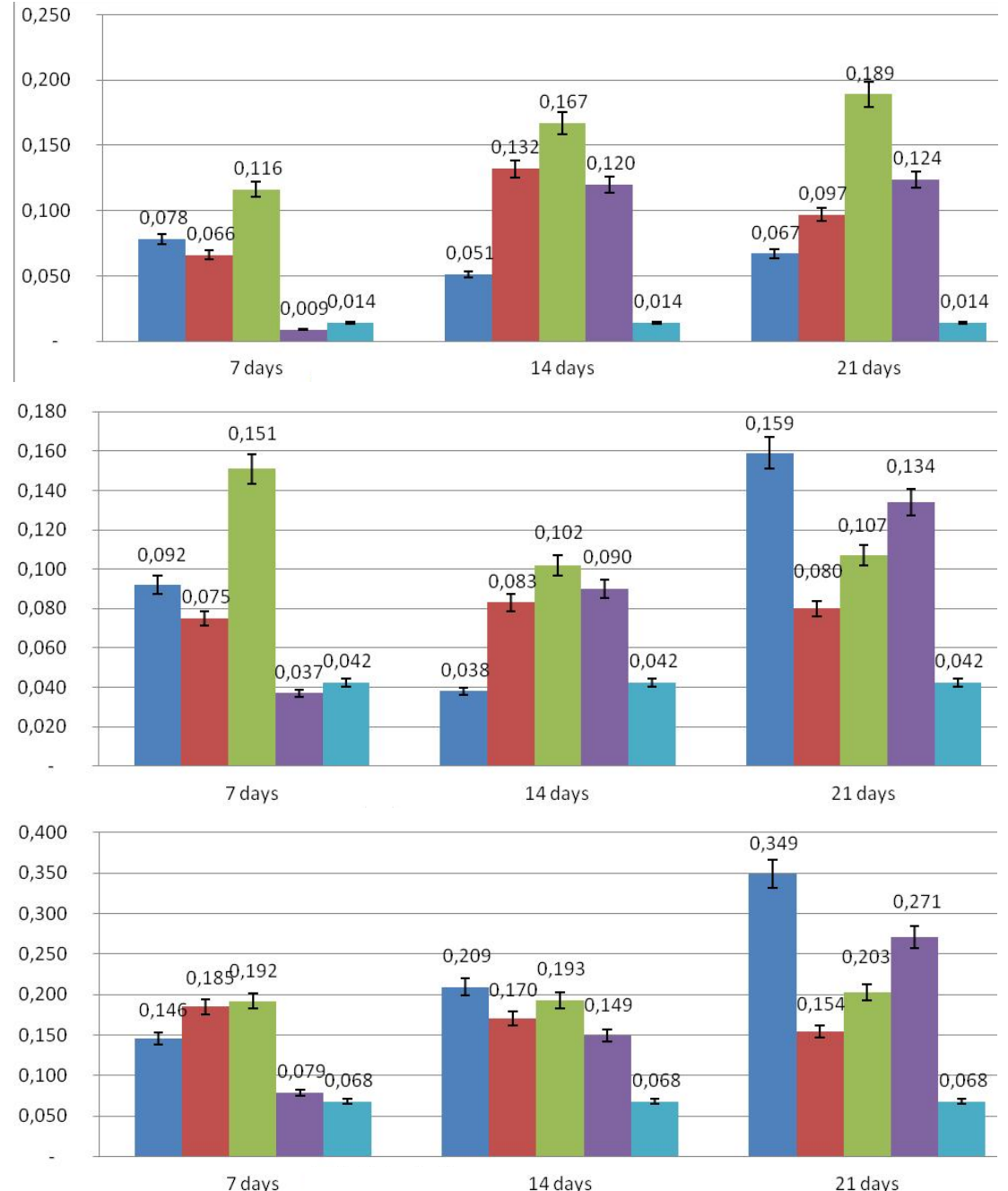

7 days
- Light deprivation

- Light deprivation using linseed oil

Light deprivation using melatonin

- Light deprivation using melatonin and linseed oil Control group

Fig. 4. Expression intensity coefficient of MT1 receptors in the epidermis during light deprivation (conventional units).

- Light deprivation

- Light deprivation using linseed oil - Light deprivation using melatonin

- Light deprivation using melatonin and linseed oil - Control group

Fig. 5. Expression intensity coefficient of MT1 receptors in the sebaceous glands during light deprivation (conventional units).

- Light deprivation

- Light deprivation using linseed oil

- Light deprivation using melatonin

- Light deprivation using melatonin and linseed oil n Control group

Fig. 6. Expression intensity coefficient of MT1 receptors in hair follicles under light deprivation (conventional units). follicles. At this stage of the experiment, there was a significant decrease in the percentage of MT1-positive cells. At the same time, the indicators of MT1 immunoreactivity remained elevated in all the studied structures of the rat skin as compared with the control values [20].

Intragastric administration of flaxseed oil and exogenous melatonin to animals for 14 days of the experiment did not have a significant effect on the level of immunopositive cells in the epidermis and hair follicles compared to the light deprivation group. However, the melatonin receptors of sebaceous gland sebocytes were found to be more sensitive to exogenous melatonin. This was manifested in a sharp increase (above the control figures) of the MT1 fill factors. At the same time, the combined administration of the oil and the hormone at this observation period contributed to a sharp increase (17.5 times, $\mathrm{p}<0.001)$ in MT1-positive areas in all skin structures compared to the light deprivation group (see Fig. 1-3). As for the severity of the intensity of immunohistochemical staining, on the 14th day there was a significant increase in the coefficients of the expression intensity of MT1 receptors in all groups of animals, both in relation to the group without the use of substances and the intact group $(p<0.001)$. At the same time, the most pronounced effect was observed in animals that were injected only with melatonin (see Fig. 4, 5, 6).

As can be clearly seen from Figures 1-3, on the 21st day of the rats being in constant darkness, there was a significant increase in the percentage of receptor-positive cells and the severity of the intensity of immunohistochemical staining in all three studied structures [6]. However, the administration of flaxseed oil, melatonin, and a combination of oil and a hormone to experimental animals for 21 days led to a decrease in the filling factors of MT1 receptors in the epidermis, sebaceous glands and hair follicles in comparison with the light deprivation group (Fig. 1-6). At the same time, the intragastric intake of melatonin contributed to the fall of the studied indicator in all studied structures below the control values.

Three-week administration of flaxseed oil and 

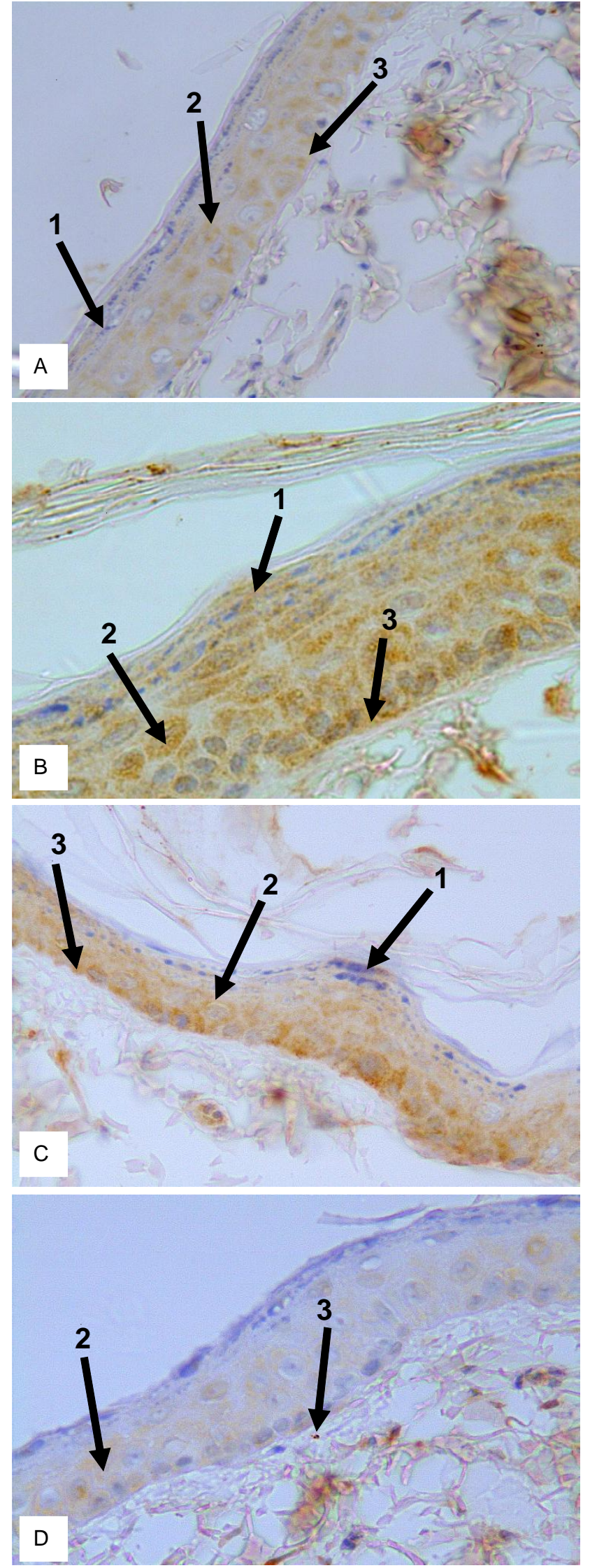

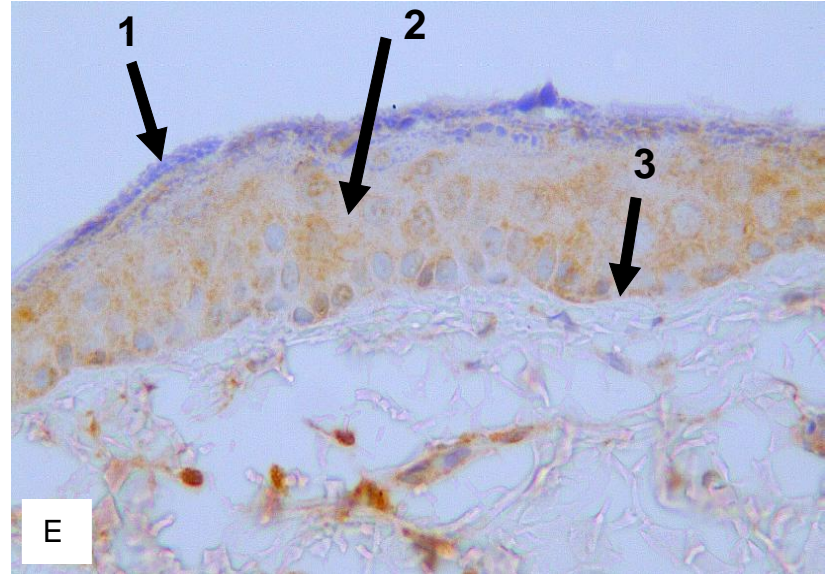

Fig. 7. Immunohistochemical detection of MT1 receptors in the cells of rats' skin epidermis during light deprivation (arrow). x400. Intact Animals (A); increased immunohistochemical response after 21 days of light deprivation (B); decrease in MT1 expression after administration of flaxseed oil (C) and combined use of flaxseed oil and melatonin (D); minimal MT1 expression after melatonin administration (E). The arrow shows MT1-positive cells of the granular (1), prickly (2) and basal (3) layers of the epidermis.

melatonin led to a slight decrease in the severity of the intensity of immunohistochemical staining relative to the light deprivation group. At the same time, the expression
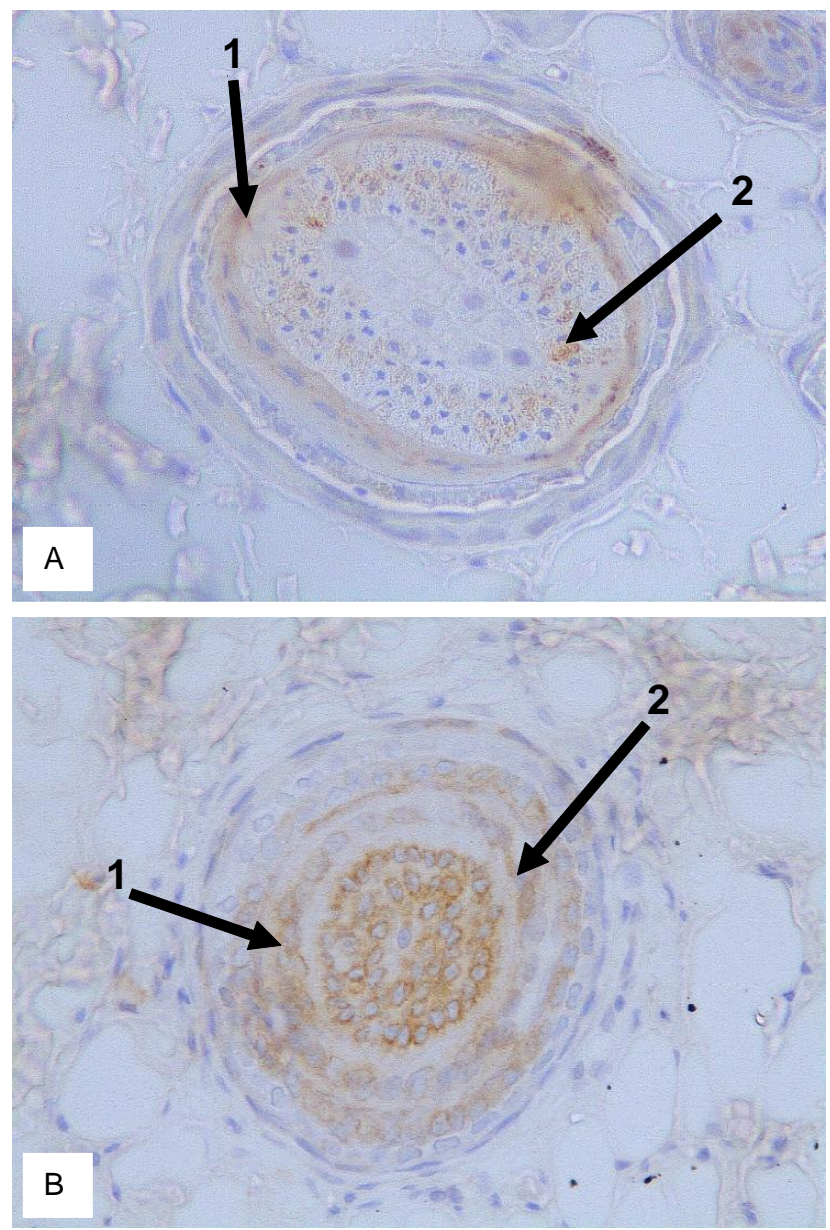


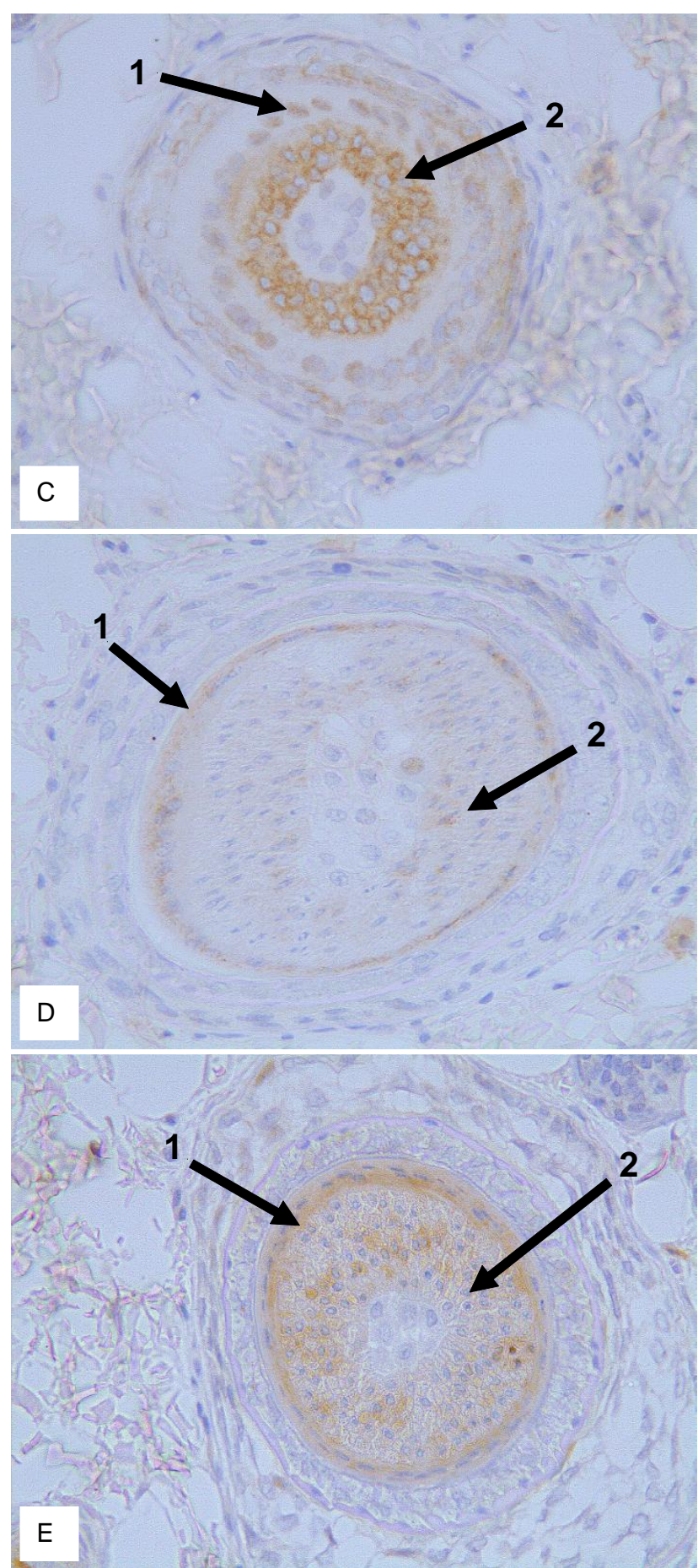

Fig. 8. Immunohistochemical detection of MT1 receptors in hair follicle cells of rat skin during light deprivation. $x 400$. Intact animals (A); increased immunohistochemical response after 21 days of light deprivation (B); decrease in MT1 expression after administration of flaxseed oil (C) and combined use of flaxseed oil and melatonin (D); minimal MT1 expression after melatonin administration (E). The arrow shows MT1-positive cells of the inner root epithelial sheath (1) and cortex (2) of the hair.

intensity coefficient still remained elevated compared to the control group $(p<0.001)$ (Fig. 7-9).
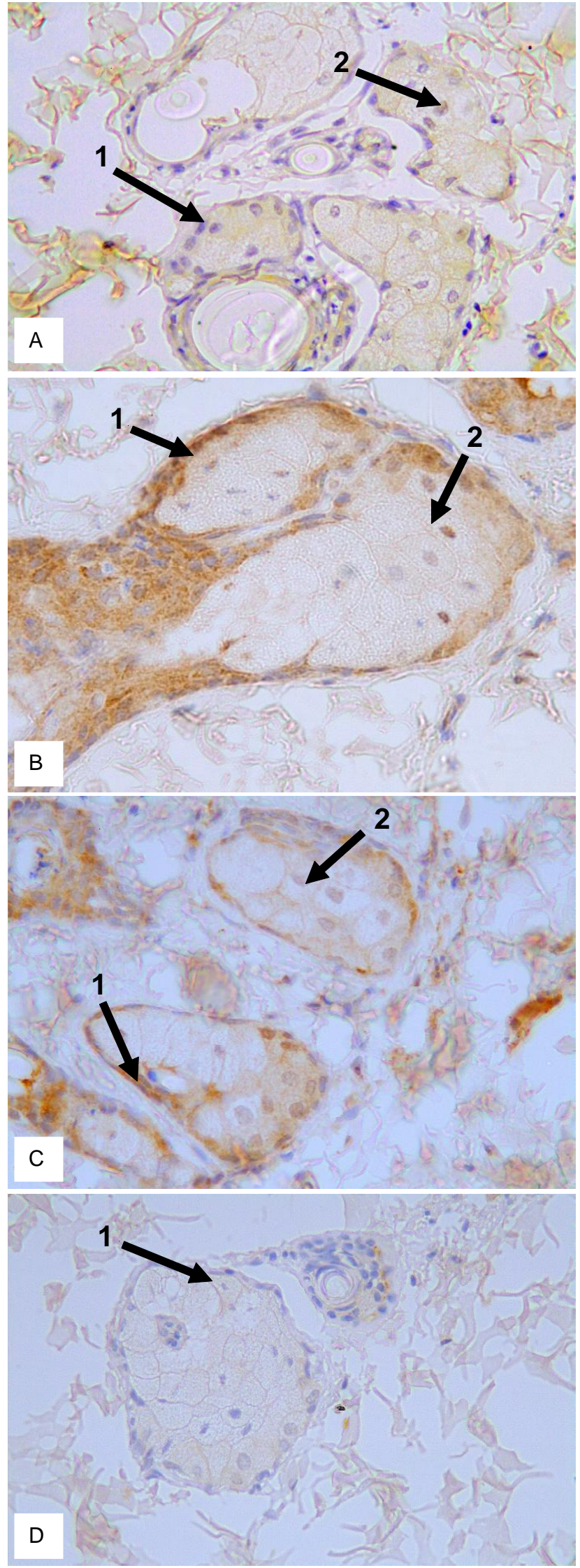


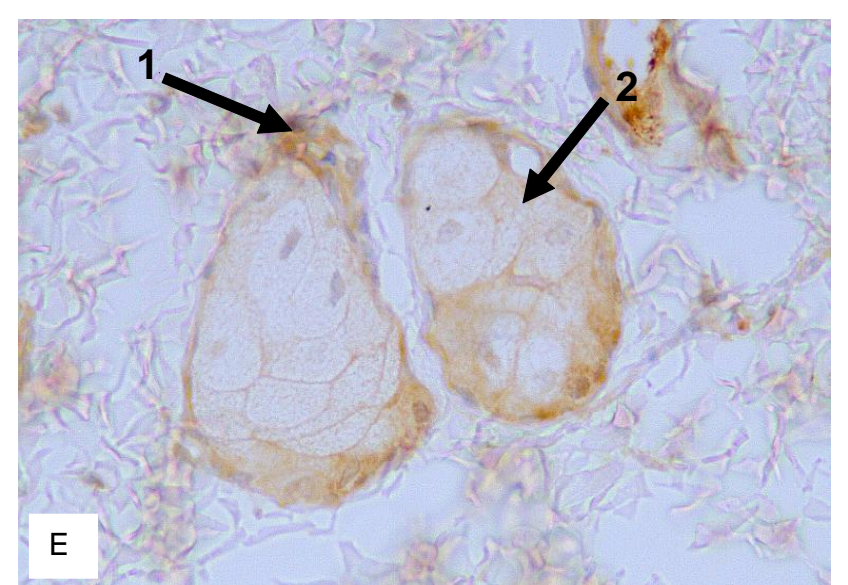

Fig. 9. Immunohistochemical detection of MT1 receptors in the cells of the sebaceous glands of rat skin during light deprivation. x400. Intact animals (A); increased immunohistochemical response after 21 days of light deprivation (B); decrease in MT1 expression after administration of flaxseed oil (C) and combined use of flaxseed oil and melatonin (D); minimal MT1 expression after melatonin administration (E). The arrow shows MT1-positive, poorly differentiated (1) and mature (2) sebocytes of the terminal sections of the sebaceous glands.

\section{Discussion}

Thus, MT1 receptors serve to bind melatonin in the skin, and their expression directly affects the effectiveness of the hormone [3, 4, 7, 12, 13, 15, 16].

The data obtained in this work provide evidence that light deprivation contributes to some destabilization of the local circadian system in the epidermis, sebaceous glands and hair follicles of experimental animals against the background of the absence of periodicity in the production of melatonin. Taking into account the fact that the most intense expression of this hormone is observed at night, in response to 24-hour darkness in animals, the level of melatonin in tissues and peripheral blood should strongly increase. The signs of this process in the present study were the destabilization of MT1 receptors in keratinocytes and sebocytes on days 7 and 14, which consisted in a decrease in their number, while the proportion of highly positive cells increased. It can be assumed that these changes occur due to qualitative (structural) and quantitative disorders of cell receptors, against the background of excessive chronic exposure to the hormone. According to the literature, a similar decrease in the number of melatonin receptors is observed with age-related changes in the skin. This leads to an increase in the proportion of damaged keratinocytes and sebocytes, and the loss of their ability to normal regeneration [3].

It is known that circulating melatonin is able to influence its own concentration according to the principle of negative feedback [4, 12]. Therefore, it is natural to assume that a longer stay of animals in the dark (for 21 days) induces a decrease in melatonin production and promotes an increase in the expression of cytoplasmic MT1 receptors in keratinocytes and sebocytes. The cells compensate for the hormonal deficiency by increasing the number of receptors on their surface, which is necessary for binding its minimal amounts.

The corrective effect of the introduction of flaxseed oil can most likely be explained by several reasons. First, it contains large amounts of essential fatty acids linoleic, $\alpha$ linolenic (maximum amount) and $\mathrm{y}$-linolenic. This oil also contains oleic, palmitic, linoleic and stearic acids [6, 14, 18]. Moreover, only linseed oil contains linoleic and $\alpha-$ linolenic acids in a ratio of $1: 1$ that is optimal for the human body [6]. It has been proven that omega- 3 fatty acids increase the content of this indole in the blood due to the synergistic regulation of the pineal gland [11, 14, 22]. Secondly, flaxseed oil is a natural source of melatonin (phytomelatonin), which may also have an effect on hormonal status [14]. Third, flaxseed oil has a high content of lignans, which act as antioxidants and phytoestrogens [5]. Thus, flaxseed oil is generally referred to as a functional food, which has high physiological benefits and reduces the risk of developing many diseases, as well as increases the protective properties of the body [11].

Consequently, with the introduction of flaxseed oil to rats against the background of light deprivation, a clear tendency to a decrease in the severity of disorders in the expression of MT1 receptors and a tendency to its normalization were manifested. This was especially pronounced on days 7 and 21 of the study.

Melatonin replacement therapy has also been shown to be effective during light deprivation. Some smoothing of the effect of an unfavorable environmental factor on melatonin receptors of epidermal cells and hair follicles was observed, but only on days 7 and 21 [2, 4, 5, 10, 12, 15]. At the same time, in sebocytes of the sebaceous glands, this effect persisted throughout the study. This phenomenon can be explained by the fact that the sebaceous glands do not belong to the structures of extrapineal synthesis of melatonin, in contrast to the keratinocytes of the skin and, therefore, sebocytes may be more sensitive to the exogenous hormone. According to studies on the effect of exogenous melatonin on rodents using various stress models, it was found that this hormone has a powerful and long-term anti-stress effect [9, 17, 23].

At the same time, the activity of flaxseed oil and melatonin increases when they are combined. So, it was found that melatonin protects omega-3 from lipid peroxidation, and also promotes the absorption of these fatty acids in the body. This increases both the level of fatty acids and the optimization of the ratio of omega- 6 and omega-3. However, omega-3 fatty acids contribute to the production of melatonin in the body. It is assumed that melatonin and omega- 3 enhance mitochondrial protection against free radical damage [21].

\section{Conclusions}

The results obtained in the course of the study lead to the following conclusions: 
1. Light deprivation is accompanied by destabilization of the expression of MT1 melatonin receptors in the epidermis, sebaceous glands and hair follicles

2. The use of flaxseed oil and melatonin as a corrector helps to level the adverse effect of desynchronosis on the

\section{References}

[1] Arzamastsev, E.V., Guskova, T.A., Berezovskaya, I.V., Lyubimov, B.I., Lieberman, S.S., \& Verstakova, O.L. (2005). Memoduческие указания по изучению общетоксического действия фрармакологических веществ. Руководство по экспериментальному (доклиническому) изучению новых формакологических веществ [Guidelines for the study of the general toxic effect of pharmacological substances. Guidelines for experimental (preclinical) study of new pharmacological substances]. Под ред. Р.У.Хабриева, Ed. R.U.Khabrieva. М.: Медицина - М.: Medicine.

[2] Bykov, M.I., Esaulenko, E.E., \& Basov, A.A. (2015). Экспериментальное обоснование использования льняного масла и масла из плодов грецкого ореха в гастроэнтерологической практике [Experimental substantiation of the use of flaxseed oil and walnut oil in gastroenterological practice]. Экспериментальная и клиническая гастроэнтерология - Experimental and Clinical Gastroenterology, 118(6), 53-56.

[3] Dong, K., Goyarts, E., Rella, A., Pelle, E., Wong, Y.H., \& Pernodet, N. (2020). Age associated decrease of MT-1 melatonin receptor in human dermal skin fibroblasts impairs protection against UV-induced DNA damage. Int. J. Mol. Sci., 21(1), 326. doi: 10.3390/ijms21010326

[4] Emet, M., Ozcan, H., Ozel, L., Yayla, M., Halici, Z., \& Hacimuftuoglu, A.A. (2016). Review of melatonin, its receptors and drugs. Eurasian J. Med., 48(2), 135-141. doi: 10.5152/ eurasianjmed.2015.0267

[5] Goyal, A., Sharma, V., Upadhyay, N., Gill, S., Sihag, M. (2014) Flax and flaxseed oil: an ancient medicine \& modern functional food. J. Food Sci. Technol., 51(9), 1633-1653. doi: 10.1007/ s13197-013-1247-9

[6] Han, Y., Deng, X., Zhang, Y., Wang, X., Zhu, X., Mei, S., \& Chen, A. (2020). Antidepressant-like effect of flaxseed in rats exposed to chronic unpredictable stress. Brain Behav., 10(6), e01626. doi: 10.1002/brb3.1626

[7] Isola, M., Ekstrom, J., Lilliu, M.A., Isola, R., \& Loy, F. (2016). Dynamics of the melatonin MT1 receptor in the rat parotid gland upon melatonin administration. J. Physiol. Pharmacol., 67(1), 111-119. doi: 10.1111/j.1600-079X.2007.00470.x

[8] Keskin, E., \& Uluisik, D. (2019). The protective effect of melatonin on plasma lipid profile in rats with cerulein-induced acute pancreatitis. Turkish Journal of Sport and Exercise, 21(2), 332-336. doi: $10.15314 /$ tsed.541829

[9] Khan, R., Morley, S., Daya, S., \& Potgieter, B. (1990). The evaluation of melatonin as a possible anti-stress hormone. In: Lubec G., Rosenthal G.A. (eds) Amino Acids. Springer, Dordrecht. doi: 10.1007/978-94-011-2262-7 120

[10] Kim, T.K., Lin, Z., Tidwell, W.J., Li, W., \& Slominski, A.T. (2015). Melatonin and its metabolites accumulate in the human epidermis in vivo and inhibit proliferation and tyrosinase activity in epidermal melanocytes in vitro. Mol. Cell. Endocrinol., 404, 1-8. doi: 10.1016/j.mce.2014.07.024

[11] Lavialle, M., Champeil-Potokar, G., Alessandri, J.M., Balasse, L., Guesne, T.P., Papillon, C. ... Denis, I. (2008) An (n-3) polyunsaturated fatty acid-deficient diet disturbs daily locomotor activity, melatonin rhythm, and striatal dopamine in Syrian hamsters. J. Nutr., 138(9), 1719-1724. doi: 10.1093/jn/ studied parameters of MT1 receptors in the epidermis, sebaceous glands and hair follicles.

3. The most pronounced effect on the expression of MT1 receptors is observed with the introduction of exogenous melatonin on the 21 st day of the experiment.

138.9.1719

[12] Liu, J., Clough, S.J., Hutchinson, A.J., Adamah-Biassi, E.B., Popovska-Gorevski, M., \& Dubocovich, M.L. (2016). MT1 and MT2 melatonin receptors: a therapeutic perspective. Ann. Rev. Pharmacol. Toxicol., 56, 361-383. doi: 10.1146/annurevpharmtox-010814-124742

[13] Mathes, A.M., Heymann, P., Ruf, C., Huhn, R., Hinkelbein, J., Volk, T., \& Fink, T. (2019). Endogenous and exogenous melatonin exposure attenuates hepatic MT1 melatonin receptor protein expression in rat. Antioxidants, 8(9), 408. doi:10.3390/ antiox8090408

[14] Peuhkuri, K., Sihvola, N., \& Korpela, R. (2012). Dietary factors and fluctuating levels of melatonin. Food \& Nutrition Research, 56. doi: 10.3402/fnr.v56i0.17252

[15] Plikus Bogi, M. V. (2018). Skin as a window to body-clock time. Proceedings of the National Academy of Sciences, 115(48), 12095-12097. doi: 10.1073/pnas.1817419115

[16] Plikus Bogi, M.V., Van Spyk, E.N., \& Pham, K. (2015). The circadian clock in skin: implications for adult stem cells, tissue regeneration, cancer, aging, and immunity. J. Biol. Rhythms, 30(3), 163-182. doi: 10.1177/0748730414563537

[17] Reiter, R.J., Tan, D.X., \& Maldonado, M.D. (2005). Melatonin as an antioxidant: physiology versus pharmacology. Journal of Pineal Research, 39, 215-216. doi: 10.1111/j.1600079X.2005.00261.x

[18] Slominski, A.T., Hardeland, R., Zmijewski, M.A., Slominski, R.M., Reiter, R.J., \& Paus, R. (2018). Melatonin: a cutaneous perspective on its production, metabolism, and functions. $J$. Invest. Dermatol., 138(3), 490-499. doi: 10.1016/ j.jid.2017.10.025

[19] Sobolevskaya, I.S., Myadelets, O.D., \& Yarotskaya, N.N. (2020). Состояние липидного обмена у крыс при световой депривации на фоне коррекции льяным маслом и мелатонином [The state of lipid metabolism in rats during light deprivation against the background of correction with linseed oil and melatonin]. Вестник Казанского национального медицинского университета - Bulletin of Kazan National Medical University, 2, 404-409. ISSN: 2524 - 0692.

[20] Sobolevskaya, I.S., Krasnobaeva, M.I., \& Myadelets, O.D. (2020). Особенности экспрессии рецепторов мелатонина MT1 в кожном покрове крыс при световой депривации [Peculiarities of expression of MT1 melatonin receptors in the skin of rats under light deprivation]. Морфологія Morphology, 14(4), 64-71. doi: 10.26641/19979665.2020.4.64-71

[21] Xu, J., Yang, W., \& Deng, Q. (2012). Flaxseed oil and a-lipoic acid combination reduces atherosclerosis risk factors in rats fed a high-fat diet. Lipids Health Dis., 11, 148. doi: 10.1186/ 1476-511X-11-148

[22] Zhao, M., Tuo, H., Wang, S., \& Zhao, L. (2020). The effects of dietary nutrition on sleep and sleep disorders. Mediators of Inflammation, 2020(3142874), 1-7. doi: 10.1155/2020/3142874

[23] Zhong, J., \& Liu, Y. (2018). Melatonin and age-related cardiovascular diseases. Aging Med. (Milton), 1(2), 197-203. doi: 10.1002/agm2.12036 


\section{ВПЛИВ ЕКЗОГЕННОГО МЕЛАТОНІНА ТА ЛЛЯНОГО МАСЛА НА СТАН ЕКСПРЕСІЇ РЕЦЕПТОРІВ МТ1 У ШКІРІ ЩУРІВ ЗА УМОВИ СВІТЛОВОї ДЕПРИВАЦІї \\ Соболевська І.С., Краснобаєва М.І., Мяделець О.Д.}

Більшість клітин шкіри володіють власною автономною функціональною циркадною системою, яка здатна контролювати фрізіологічні та біохімічні процеси в загальному покрові. Особлива роль у иих процесах відводиться "вартовому" гормону епіфріза мелатоніну, котрий впливає на клітини-мішені за допомогою специрічних рецепторів (MT1, MT2, MT3 і RORa). Будьякий розлад добових ритмів може призводити до перебудов (порушень) у рецепторному апараті клітин загального покриву, що вимагає певної корекції. Отже, виникає необхідність у пошуку дієвих і надійних препаратів, що дозволять запобігти негативним наслідкам, викликаних хронодеструкцією. У даній роботі проведено дослідження ефективності впливу екзогенного мелатоніну і лляного масла на експресію рецепторів MT1 в загальному покриві щурів при світловій депривації. Експериментальне дослідження було проведено на 130 білих безпородних щурах-самиях (170-220 г), яких випадковим чином розподілили на 5 груп: інтактна, тварини з моделюванням світлової депривації, тварини з моделюванням світлової депривації, яким внутрішньошлунково вводили лляне масло і мелатонін. На 7, 14 і 21 добу забирали гістологічний матеріал (фррагменти шкіри міжлопаткової області спини). Для іммунногістохімічних досліджень серійні зрізи фрарбували з використанням поліклональних антитіл MTNR1A. Для морфометричного аналізу даних застосовували комп'ютерні програми Image Scope Color i ImageJ. Всю статистичну обробку даних проводили за допомогою програми Statistica 10.0. Відмінності вважали достовірними за умови р<0,01. В ході експерименту було встановлено, що світлова депривація сприяє зміні активності експресії рецепторів мелатоніну MT1 в епідермісі, сальних залозах і волосяних фролікулах. Проведені дослідження показали, що введення щурам з десинхронозом лляної олії, мелатоніну, а також їх комбінації супроводжується нівелюванням несприятливого впливу десинхроноза на досліджувані параметри рецепторів МТ1. Найбільш виражений корекційний ефект на експресію рецепторів МT1 спостерігається при введенні екзогенного мелатоніну на 21 добу експерименту.

Ключові слова: рецептори мелатоніну МT1, епідерміс, сальні залози, волосяні фолікули, мелатонін, лляне масло, світлова депривація. 